Article

\title{
Influencing Mechanism of Green Human Resource Management and Corporate Social Responsibility on Organizational Sustainable Performance
}

\author{
Fuqiang Zhao ${ }^{1}$, Manita Kusi ${ }^{1}$, , Yun Chen ${ }^{1, *}$, Wei Hu ${ }^{1}$, Fawad Ahmed ${ }^{1} \mathbb{D}$ and Dinesh Sukamani ${ }^{2} \mathbb{C}$ \\ 1 School of Management, Wuhan University of Technology, 122 Luoshi Road, Hongshan District, \\ Wuhan 430070, China; zhaofq@whut.edu.cn (F.Z.); manyatasth2@gmail.com (M.K.); \\ 290146@whut.edu.cn (W.H.); fawadahmed1@live.com (F.A.) \\ 2 Department of Civil Engineering, Nepal Engineering College-CPS, Lalitpur 44700, Nepal; \\ dsukamani@gmail.com \\ * Correspondence: cheny@whut.edu.cn
}

\section{check for} updates

Citation: Zhao, F.; Kusi, M.; Chen, Y.; $\mathrm{Hu}, \mathrm{W}$;; Ahmed, F.; Sukamani, D. Influencing Mechanism of Green Human Resource Management and Corporate Social Responsibility on Organizational Sustainable Performance. Sustainability 2021, 13, 8875. https://doi.org/10.3390/ su13168875

Academic Editor: Carla Maria Marques Curado

Received: 7 July 2021

Accepted: 2 August 2021

Published: 9 August 2021

Publisher's Note: MDPI stays neutral with regard to jurisdictional claims in published maps and institutional affiliations.

Copyright: (c) 2021 by the authors. Licensee MDPI, Basel, Switzerland. This article is an open access article distributed under the terms and conditions of the Creative Commons Attribution (CC BY) license (https:// creativecommons.org/licenses/by/ $4.0 /)$.

\begin{abstract}
Sustainable organizational achievement of firms is the dominant approach in today's world, with an inclination on improving profitability, social condition, and a healthy environment. Based on ability, motivation, opportunity (AMO), and stakeholder theories, this study explored the green human resource management (GHRM) and corporate social responsibility (CSR) mechanism towards sustainable performance achievement. A structured questionnaire survey from 305 samples was appropriate for the quantitative study on this research. Moreover, widely used structural equation modeling and analysis of moment structures (AMOS) was used to analyze the proposed structural model of the study. Findings from the study added significance to all posited hypotheses and validated the study model. The current study added literature to the body of knowledge on green human resource management practices and corporate social responsibility in the pursuit of improved performance towards society, the environment, and sustainability of construction firms. For future studies, the inclusion of industries such as transportation-based industries and manufacturing companies that contribute to development should be considered for broad learning.
\end{abstract}

Keywords: construction firms; sustainability; green human resource management; corporate social responsibility; SEM AMOS

\section{Introduction}

Intervening new innovative ideas in business through adopting and implementing socially responsible activities and green practices in the organization is an ongoing concept over a few decades [1]. Corporates' social responsibility and concern for the environmental aspect are directly proportional to the wellbeing of the employees [2]. According to Jackson et al. (2011), organizations, like other populations, are obligated to serve the society they operate their business in and shall reserve their knowledge base [3]. The most widely accepted definition of sustainability is "development that meets current needs without compromising future generations' needs" [4]. Past research has examined green and social responsibility concepts in different industries including the manufacturing sector $[5,6]$, hospitality and tourism [1,2,7], and healthcare [7]. Moreover, construction companies [8], being a key contributor to development, have also been of interest to researchers with the inclusion of green concepts and social responsibility. The social economy concept has been explained in prior research to emphasize the importance of social responsibility inclusion to achieve sustainability objectives of the organization [9].

Environmental protection is a significant problem for today's businesses, which must strike a balance between economic growth and environmentally responsible operations. GHRM is a new field related to human capital that prioritizes the employees' attitude 
development on the environmentally conscious organization [10]. Moreover, another study explained the green credentials for different types of sustainable human resources [11], social responsibility, triple bottom line, common good, and green human resource management. Among them, green human resource management is considered an environmental dimension. Green human resource management (GHRM) is a set of activities associated with the initiation, implementation, and continuous maintenance to sustain the green concept among employees within the organization [6]. Employees must be motivated, empowered, and ecologically conscious when it comes to green projects, and such awareness is critical when it comes to developing ecologically creative solutions [12]. Moreover, GHRM is a human resource approach that supports environmentally conscious business and management. It increases employees' environmental knowledge, which translates into the long-term viability of practices across firms [13].

Meanwhile, when an organization internalizes values that align with societal aspirations, it exhibits respect for its workers, the environment, the law, and the society in which it operates [14]. Further, the concept of greater emphasis on social responsibilities is not confined to developed nations. As a result of globalization, many firms in the developing countries are incorporating CSR principles into their operations [15]. A firm's commitment to seek long-term goals [16] that are good for society, beyond what is required by law [17] and economics [18], is known as corporate social responsibility. The consistency of a human system based on a set of ethical values, such as justice, dignity, and loyalty, is referred to as social sustainability [2]. That is why corporate social responsibility has been added in this study to investigate its impact upon sustainable performance. Green activities from an environmental perspective and CSR covering the social perspective help the firms to attain competitive advantage and achieve sustainable performance. Sustainability is not just in numerical terms and monetary form but takes an interest in the climate and general wellbeing of staff, society, customers, and other stakeholders.

This academic research developed a moderated mediation model integrating social and behavioral perspectives at the micro-level. To our knowledge, only a few studies have looked at how GHRM, affective commitment (AC), perceived organizational support (POS), and social responsibility may be used to measure long-term success in the construction industry. Prior researchers introduced social responsibility human resources $[19,20]$ regarding the inclusion of internal stakeholders of the organization. At the same time, one researcher explained that the three figures of social responsibility, human resource, and sustainability have grown and interacted through time, tied together by a succession of connecting components such as stakeholders or green management. This relationship has produced a political quandary within companies when it comes to defining competencies and functions across CSR, HRM, and long-term management, where a power balance has been established [21]. A review paper published in Web of Science concluded the high essence of study, including CSR and GHRM issues, towards sustainable business performance [22].

Literature, in general, places greater priority on the need for CSR activities in any organization's sustainability in the present generation; however, it is unclear whether every organization is practicing CSR in real life or not. Research brings to the forefront the latest practices and trends, which motivate the firms for their commercial gains as well as to maintain a positive corporate image. Therefore, it is critical to investigate the measures undertaken by companies in an attempt to minimize environmental instabilities and achieve permanent growth. Given the paucity of research in this area, it is useful to identify gaps and offer potential solutions [23]. The relevant material on GHRM is primarily focused on the Western world [24]. Given the economic importance in development and environmental crises, it is also critical to investigate these issues in Asia. Hence, GHRM in the context of Nepal is still under-researched. The objective of this study is also to identify the gaps while exploring the status of GHRM practices in construction firms of Nepal. 


\section{Theoretical Basis and Literature Review}

\subsection{Theoretical Perspectives}

The lens of AMO and stakeholder theory will help better understand GHRM and corporate social responsibility.

\subsubsection{Stakeholder Theory}

Stakeholder theory focuses on an organization's morality and its values [25]. The principle states that an organization has several stakeholders, each of which is involved in and influenced by the organization's performance. Since stakeholders' interests are always self-centered, they can have divergent or even conflicting interests [26]. The environment is the most important concern for stakeholders [13,26], as the 'balanced scorecard' necessitates a multi-dimensional research framework for human resource management, with different teams rating several organizational sustainability metrics. Employee motivation, green practices, and CSR activities will boost employee involvement and work efficiency [27].

Freeman (1984) says the stakeholder approach suggests that stakeholders are a group or policies that directly or indirectly influence the organization's activities and decisionmaking. Prior scholars [25] investigated various stakeholder perspectives to assess how they influence the financial outcome of the organization. The internal and external stakeholders influence the individual performance of the organization when affective commitment and job satisfaction indirectly affect CSR and employee performance [21]. A research scholar established critical elements in construction firms of CSR to disclose particular contents included in the performance issue based on stakeholder theory [28]. The scholar further elaborated that construction companies value CSR as one of the major factors contributing to sustainable business development. Construction companies in the UK have their level of understanding regarding CSR and their recognition of CSR that may be challenging for them to persuade a range of stakeholders that their CSR obligations are real and independently verifiable [29].

\subsubsection{AMO Theory}

The organization's sustainability is achieved through green human resource practices accumulating social and environmental needs [30]. Jabbour et al. (2011) defined GHRM as a deliberate integration of traditional human resource management techniques with an organization's environmental objectives [31]. A quantitative research survey in manufacturing organizations examined the relevance of the supply chain and GHRM through ability motivation and opportunity to enhance financial performance [32]. The ability, motivation, opportunity (AMO) theory guides the employees in acknowledging their abilities and motivates them on the environmental activities and provides opportunities to improve in environmental aspects [33]. Moreover, in the Asian context, GHRM based on AMO theory has added evidence on the firm performance in education institutes of China [16]. Similarly, a qualitative comparative approach in the international context of three European firms showed the evidence of proactive environmental management [34]. From the GHRM perspective, the literature shows that all HRM functions can become GHRM functions and build environmentally sustainable staff and green organizational skills that are essential to an organization's environmental success [35].

\section{Hypothesis 1 (H1). GHRM is positively related with OP.}

Hypothesis $2 \mathbf{( H 2 )}$. CSR is positively related with OP.

\subsection{Mediating Role of Perceived Organizational Support}

Perceived organizational support (POS) is termed as the observation by workers as to how much an organization values their efforts and takes care of their overall wellbeing that meets the socio-emotional needs of an employee [36]. In general, companies operate to portray themselves as an important symbol at the center of their workers through social 
exchange channels. As a result, employees form social exchange connections with their employers, which are often based on the sense of employee involvement and gratitude from their employers [37].

Employees must obtain support and appreciation from their employers to explore innovative solutions to work-related issues. Either approach might entail enlisting employees in activities that are unrelated to their primary responsibilities and demonstrating that their employer or coworkers benefit [38]. The intervening part of perceived organizational support between green human resource management and organizational performance still needs to be studied. Recent research on the influence of green human resource management practices on green behaviors also adopted the intervening role of green knowledge sharing to explore the sustainable performance of the organization [39].

Hypothesis 3 (H3). POS mediates the relation between GHRM and OP.

Hypothesis 4 (H4). POS mediates the relation between CSR and OP.

\subsection{Mediating Role of Affective Commitment}

The emotional attachment of an employee towards its company is termed as affective commitment [40]. Employees with a high level of emotional commitment want to stay at their company because of the pleasant sensations they get from their connection with it. The role of affective commitment to human resource management is proving the cornerstone to improvise the human capital of the organization [41]. Workplace behavior and the relationship shared by the employees and their firms are highly affected by the commitment of employees [42]. Prior research on the hotel industry explored the link between GHRM and the environmental performance of hotels through the organizational commitment of employees and eco-friendly actions in two separate settings (green and non-green hotels). Kim et al. (2019) concluded that employee concern on eco-friendly behavior and performance inclination towards the environment has a significant link with their commitment [43].

Hypothesis $\mathbf{5}$ (H5). AC mediates the relation between GHRM and OP.

Hypothesis 6 (H6). AC mediates the relation between CSR and OP.

\subsection{Green Transformational Leadership as Moderator}

Green transformational leadership is seen as a key element for rising organizations' green efficacy [44]. It empowers workers to perform efficiently when considering green self-efficacy. In particular, supervisory support and encouraging senior management promote environmental actions by employees to produce environmentally friendly products with lesser resources and help pollution reduction. Meanwhile, sustainable organizational performance can be directly linked with the leaders and their role in improving the creativity for environmental performance output [45]. Moreover, GTL fully exemplifies the beliefs, attitudes, values, and behavior of the higher-level management and this direct link with organizational performance [44]. This study considered transformational leadership because it has an idealized influence [46] and provides a huge source of motivation and uses intellectual stimulation [47]. Exceptional to the other study, this research tried to investigate the new moderation role of transformational leadership in the relationship between GHRM and POS. On purpose, the following hypothesis is posited:

Hypothesis 7 (H7). GTL moderates the mediated model on the relationship between GHRM and OP such that the effect of GHRM on OP is stronger when GTL is high than when it is low. 


\section{Methodology}

\subsection{Data and Study Sample}

Construction companies directly affect environmental hazard production and management. Since this study is focused on the green impact of the organization towards sustainable organizational performance, it was worth choosing the construction firm as a study area. Further, the industry also equally contributes to implementing social responsibility practices are industry dependent, and the construction industry is also expected to implement and practice the social responsibility through their level. Therefore, it provides a suitable context for this research. This research used cross-sectional survey design to examine the hypothesis related to the association between green human resource management, corporate social responsibility, affective commitment, perceived organizational support, and organizational performance. The sample included 315 employees working in construction companies.

\subsection{Study Instrument}

Management research widely uses the questionnaire survey method to collect data. Furthermore, to collect data with a larger sample size, the questionnaire is assumed to be suitable tool for respondents to respond. A five-point Likert scale was used to measure the GHRM, CSR, AC, POS, GTL, and OP. The research utilized a multi-item Likert scale to measure the study variables $(1=$ strongly disagree, $5=$ strongly agree). The preference of a five-point Likert scale over seven is that the five-point scale appears to be less confusing and to increase response rate and reliable data [48]. The constructs used for the questionnaire are shown in Appendix A with Cronbach's alpha values of major constructs.

\subsection{Statistical Analysis}

This research used the SPSS statistical program which conducts both contrast and correlation statistical analyses in the sense of univariate, bivariate, and multivariate analysis for both parametric and non-parametric statistical methods. Further, to measure the measurement and structure analysis, a covariance-based SEM methodology, Analysis of Moment Structures (AMOS version 21.0), was used for the current research to evaluate and analyze the data within the proposed model.

\section{Results}

The sample of 305 responses was esteemed satisfactory for SEM investigation as it surpassed the edge level of 200. In the demographic context, there were $215(70 \%)$ male respondents and 90 (29.51\%) female respondents. From an educational level perspective, the majority of employees had undertaken a postgraduate level of study, while around $11 \%$ of them were graduates and the rest $(12 \%)$ were studying at the graduate degree level. The majority of the employees were involved in the construction organizations, with ten years' work experience (29\%). Moreover, an equal percentage of employees had obtained experience of 0-3 years and 4-6 years, and the rest had experience between 7 and 9 years. In addition, the study tried to cover all types of organizations; among them, a maximum number of participants were the employees of government-owned organizations $(68 \%)$, while a minimum number of participants were from non-profit organizations and public enterprises.

Moreover, all skewness values of each indicator of all constructs were found to be normally distributed. In addition, a KMO (Kaiser-Meyer-Olkin measurement) sample adequacy test for this study was performed. The result $(K M O=0.819)$ shows that the sample size for the key component analysis was adequate and acceptable for implementation. The composite reliability (CR) value for the sample was obtained above 0.8 , while convergent validity and discriminant validity for the sample met the cutoff value [49] of 0.5 , confirming that factors of the study had adequate convergent validity and reliability as illustrated in Tables 1 and 2. 
Table 1. Construct reliability and convergent and discriminant validity.

\begin{tabular}{ccccccccccc}
\hline & CR & AVE & MSV & MaxR(H) & GHRM & GTL & CSR & OP & POS & AC \\
\hline GHRM & 0.860 & 0.606 & 0.124 & 0.869 & $\mathbf{0 . 7 7 8}$ & & & & & \\
GTL & 0.908 & 0.666 & 0.124 & 0.917 & 0.352 & $\mathbf{0 . 8 1 6}$ & & & & \\
CSR & 0.937 & 0.789 & 0.162 & 0.945 & -0.004 & 0.018 & $\mathbf{0 . 8 8 8}$ & & & \\
OP & 0.894 & 0.680 & 0.061 & 0.910 & 0.037 & -0.002 & -0.150 & $\mathbf{0 . 8 2 5}$ & & \\
POS & 0.870 & 0.626 & 0.212 & 0.873 & -0.124 & -0.110 & 0.402 & 0.246 & $\mathbf{0 . 7 9 1}$ & \\
AC & 0.913 & 0.778 & 0.212 & 0.922 & 0.039 & -0.082 & 0.375 & -0.006 & 0.460 & $\mathbf{0 . 8 8 2}$
\end{tabular}

Note: Bold values on the diagonal of the correlation matrix are the square root of AVE (discriminant validity) CR: construct reliability; AVE: average variance extracted.

Table 2. Fornell-Larcker criterion analysis.

\begin{tabular}{ccccccc}
\hline & AC & CSR & GHRM & GTL & OP & POS \\
\hline AC & 0.891 & & & & & \\
CSR & 0.356 & 0.889 & & & & \\
GHRM & 0.016 & -0.02 & 0.776 & & & \\
GTL & -0.091 & 0.016 & 0.32 & 0.788 & & \\
OP & 0.016 & -0.102 & 0.032 & -0.013 & 0.817 & \\
POS & 0.466 & 0.409 & -0.129 & -0.126 & 0.283 & 0.791 \\
\hline
\end{tabular}

Note: The discriminant validity is ascertained when the square root of AVE of a construct is greater than its correlation coefficients with other constructs [50].

As data were collected from a single source at one point in time, common method bias (CMB) could be an issue. Hence, Harmon's one-factor test was conducted using SPSS to check CMB. The output confirmed the absence of $\mathrm{CMB}$ from our data set as the first factor explained only $22.156 \%$ variance, which is less than the threshold value of $50 \%$.

\subsection{Analysis and Validity of Structural Model and Hypotheses Testing}

This study also followed the widely used analysis technique of SEM [51]. From the analysis run in AMOS, the output of the study sample depicted the values as CMIN $=415.84 ; \mathrm{df}=144$; $\mathrm{CMIN} / \mathrm{df}=2.880 ; \mathrm{GFI}=0.878$; $\mathrm{AGFI}=0.8390 ; \mathrm{CFI}=0.931$; $\mathrm{TLI}=0.918$; $\mathrm{RMSEA}=0.078$. Further, the path coefficient shows the conventional change of the endogenous construct with a unit change in the predictor construct. The beta value is an analysis between all latent variables; the greater the beta value, the stronger or greater the effect of the exogenous (predictor) variable on the endogenous (dependent variable) [52]. Table 3 illustrates that the majority of hypotheses are significant at $1 \%$ and $5 \%$ levels of significance.

Table 3. HTMT criterion to assess discriminant validity.

\begin{tabular}{ccccccc}
\hline & AC & CSR & GHRM & GTL & OP & POS \\
\hline AC & & & & & & \\
CSR & 0.348 & & & & & \\
GHRM & 0.062 & 0.044 & & & \\
GTL & 0.091 & 0.035 & 0.349 & & \\
OP & 0.061 & 0.112 & 0.066 & 0.062 & & \\
POS & 0.476 & 0.41 & 0.128 & 0.121 & 0.274 & \\
\hline
\end{tabular}

Note: The heterotrait-monotrait ratio (HTMT) values of the given table expose the correlations between the model's constructs where the HTMT value of less than 0.85 indicates discriminant validity.

The results shown in Table 3 clearly illustrate that $\operatorname{GHRM}\left(\beta=0.312^{* * *}\right), \operatorname{POS}\left(\beta=0.471^{* * *}\right)$, $\operatorname{CSR}\left(\beta=0.113^{*}\right)$, and $\mathrm{AC}\left(\beta=0.123^{*}\right)$ were found to be a significant and positive influence on sustainable organizational performance $(\mathrm{OP})$. Hence $\mathrm{H} 1$ was supported. The direct relation of all the variables was found to have positive significance concerning organizational performance. The first hypothesis $\mathrm{H} 1$ was supported with the values shown in Table 4, yielding a similar outcome as that of the prior researchers showing a significant positive relation of GHRM to OP of the organization $[53,54]$. The posited hypothesis is 
also supported by results of a previous study on Jordanian hospitals that reported a statistically significant positive correlation between GHRM activities on a case-by-case basis and organizational environmental performance [55]. The study added empirical evidence to the GHRM OP relation. Results are also supported by prior research [56,57], adding to empirical evidence on the significant positive impact of POS on OP. Furthermore, affective commitment also influences sustainable organizational performance directly. This research adds to available empirical evidence for the hypothesized relation of AC to OP, with similar outcomes reported by prior researchers [58,59].

Table 4. Testing all direct hypotheses in the structural model.

\begin{tabular}{ccccccc}
\hline & Relation & & Estimate & S.E. & C.R. & $p$ \\
\hline GHRM & $\rightarrow$ & OP & -0.312 & 0.053 & -5.198 & $* * *$ \\
GHRM & $\rightarrow$ & AC & 0.400 & 0.053 & 7.626 & $* * *$ \\
GHRM & $\rightarrow$ & POS & 0.415 & 0.036 & 8.055 & $* * *$ \\
CSR & $\rightarrow$ & OP & 0.113 & 0.046 & 2.208 & $0.027^{*}$ \\
CSR & $\rightarrow$ & POS & -0.143 & 0.037 & -2.768 & $0.006^{* *}$ \\
CSR & $\rightarrow$ & AC & 0.037 & 0.054 & 0.711 & $0.047^{*}$ \\
POS & $\rightarrow$ & OP & 0.471 & 0.072 & 8.357 & $*_{* *}^{*}$ \\
AC & $\rightarrow$ & OP & -0.123 & 0.049 & -2.217 & $0.027^{*}$ \\
\hline
\end{tabular}

Note: Standard error-S.E.; significance level, $p=0.05$ level $^{*}, 0.01$ level ${ }^{* *}, 0.001$ level $^{* * *}$.

Moreover, the hypothesized path from GHRM $\left(\beta=0.415^{* * *}\right)$ to POS was also significant. Additionally, the hypothesized path from CSR $\left(\beta=0.143^{* *}\right)$ to POS was also significant. Prior researchers have found a significant positive relation between CSR and POS [60,61]. In the case of a broader stakeholder view of CSR, both external and internal stakeholders are taken care of so that the CSR leads to POS [62]. Both these claims are empirically proven by the results of this research. Moreover, the posited hypothesis of GHRM's direct relation to affective commitment proved significant. The analysis yields results that are consistent with prior research showing a significant positive effect [7].

\subsection{Mediating Effect}

The fit indices obtained from the AMOS analysis revealed the model fit values with $\chi^{2}=298.488 ; \mathrm{DF}=84 ; \mathrm{CFI}=0.928 ; \mathrm{GFI}=0.896 ; \mathrm{TLI}=0.909 ; \mathrm{RMSEA}=0.09 ;$ standardized root mean square residual $(\mathrm{RMR})=0.0505$; and PCLOSE $=0.001$. These fit indices jointly claim that the total performance of the model structure is sufficient $[63,64]$. Further, the research tried to explain the association among the research variables from the structural equation model. The model has two mediating variables, and the relation consists of GHRM-POS-OP, GHRM-AC-OP, CSR-POS-OP, and CSR-AC-OP paths.

In the $\mathrm{GHRM} \rightarrow \mathrm{POS} \rightarrow \mathrm{OP}$ relation, $\mathrm{POS}$ mediates the direct relation between $\mathrm{GHRM} \rightarrow \mathrm{OP}$. The beta value of GHRM $\rightarrow$ OP is -0.286 , and the beta value of the GHRM $\rightarrow$ POS $\rightarrow$ OP relation is $0.183^{* * *}$ as shown in Tables 4 and 5. The beta value of the direct and indirect effect is in a different direction; that is, GHRM $\rightarrow$ OP is negative while GHRM $\rightarrow$ POS $\rightarrow$ OP is positive. According to Baron and Kenny (1986), there exists a competitive partial mediation on the mediating effect of POS on GHRM $\rightarrow$ OP.

Table 5. Statistical analysis of hypothesis.

\begin{tabular}{|c|c|c|c|c|c|c|c|}
\hline Hypothesis & Relationship & Estimate & Lower & Upper & S.E. & $p$-Value & Conclusion \\
\hline H3 & $\mathrm{GHRM} \rightarrow \mathrm{POS} \rightarrow \mathrm{OP}$ & 0.174 & 0.127 & 0.233 & 0.034 & $0.000 * * *$ & Supported \\
\hline H4 & $\mathrm{CSR} \rightarrow \mathrm{POS} \rightarrow \mathrm{OP}$ & 0.061 & 0.078 & 0.012 & 0.027 & 0.024 * & Supported \\
\hline H5 & $\mathrm{GHRM} \rightarrow \mathrm{AC} \rightarrow \mathrm{OP}$ & -0.044 & -0.078 & -0012 & 0.021 & 0.020 * & Supported \\
\hline H6 & $\mathrm{CSR} \rightarrow \mathrm{AC} \rightarrow \mathrm{OP}$ & -0.004 & -0.18 & -0.003 & 0.006 & $0.027 *$ & Supported \\
\hline
\end{tabular}

On the contrary, the GHRM $\rightarrow$ POS $\rightarrow$ OP relation yields an indirect effect value $\left(\beta=-0.041^{* *}, p<0.05 \%\right)$. The beta value for this relation is negative, and the beta value of 
GHRM $\rightarrow$ OP is also negative. Hence, complementary partial mediation for the mediating effect of AC on GHRM $\rightarrow$ OP direct effect beta values are either in the positive or negative value direction. Thus, the posited hypothesis is supported at a $1 \%$ and $5 \%$ level of significance.

\subsection{Moderating Effect}

Notably, the present study found a major scholarly gap of a moderating effect of green transformational leadership on the relationship between GHRM and OP, and findings reveal a significant positive effect. The moderating effect of green transformational leadership was calculated from the AMOS analysis. The beta values obtained from the analysis are used to plot a graph to obtain the interaction slope as shown in Figure 1. The interaction effect from the results with a beta value $(\beta=0.063 *, p<0.05)$ revealed a significant moderating effect of GTL. As hypothesized, a significant moderation relationship existed, whereby a higher level of transformational leadership strengthens the positive associations between green human resource management and perceived organizational support. The graphical presentation in the figure displays the relationships between GHRM and POS as moderated by GTL. Hence, it suggests that when the organization has leaders who inspire green initiatives, goals, and vision and facilitate employees accordingly, the results from employees perceiving support from the organization leads to motivation to enhance better innovative ideas and to perform with their best. This result gives credence to a recent study that showed that green transformational leaders promote green innovation by inspiring people with their green environmental initiatives, providing a clear environmental vision, and motivating staff to think about and share green ideas and practices [65].

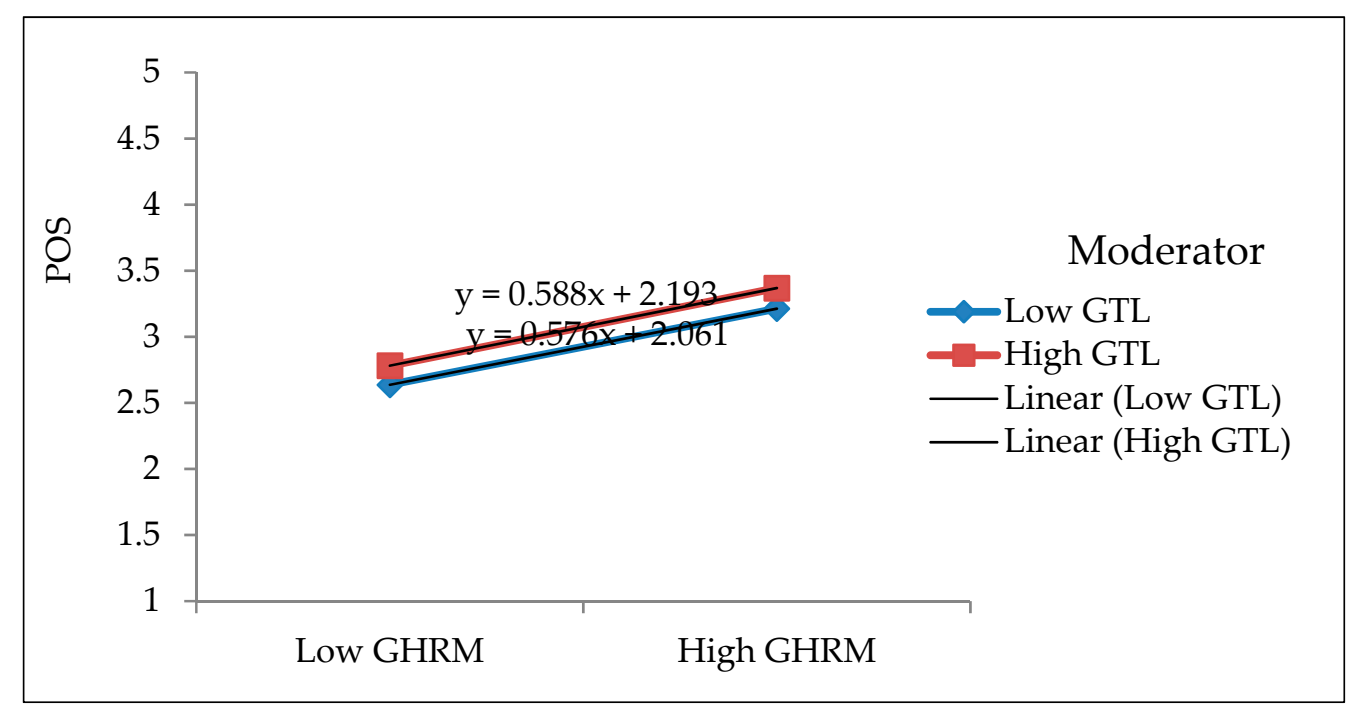

Figure 1. Interaction effect of GTL on GHRM and POS. Note: GTL strengthens the positive relationship between GHRM and POS.

\section{Discussion}

The study investigated the mechanism of GHRM and CSR on the sustainable performance of the construction organization as shown in Figure 2. The results support and advance the significant results of prior research of GHRM on OP [27,66-68]. Contrary to the results of prior studies $[9,22,63]$, this study's analysis found a positive relationship between CSR and OP. These findings strengthen the empirical evidence for CSR's positive influence on productivity while also reinforcing the widely held belief that CSR initiatives deplete resources and reduce a company's competitiveness. The current study generated hypotheses that green HRM practices and CSR are strongly related to sustainable performance focused on $\mathrm{AMO}$ and stakeholder theory. 




Figure 2. Structural model with beta values and significance level.

GHRM's direct relation to $A C$ is also supported with the value $\left(\beta=0.400^{* * *}, p>0.001\right)$. This implies that employees' trust in the perceived advantages of environmental commitment is strengthened. As a result, they are more motivated to make additional sacrifices to ensure the organization's sustainable goals are met in the long run, consistent with prior results [69]. Based on the previously reported results, this study also explored the relation between GHRM-POS and CSR-POS in order to add to knowledge and provide evidence for future studies. As expected, the analysis yielded a positive significant effect that matched the results of previous studies [70,71]. A survey conducted in tourism and hospitality industries in southwest China has emphasized the importance of GHRM, CSR, and POS to enhance the employees' involvement and improve productivity [71]. The relation between green human resource and corporate social responsibility influences the organizational support perceived by the employees.

Moreover, POS further fosters individuals' performance in collaborating and identifying new ways of working, resulting in high performance. The organizational support might be one of the important aspects to advance the employees' commitment to achieve better organizational performance. Further, prior studies have explored the positive mediating effect of POS on different variables [70,71]. On that note, this study added a novel attempt to study the mediating effect of POS on the relation of GHRM, CSR, and OP, which was found to be significantly positive.

This study also examined the mediating role of another variable, i.e., affective commitment (AC) between the GHRM-OP and CSR-OP relationships. The findings confirm the statistical significance of the mediating role of affective commitment between GHRM and $\mathrm{OP}$, which is in line with a prior study where commitment has been found to mediate the relationship between GHRM and green recovery performance [72]. Similarly, prior research points out the significance of positive affective responses of employees such as affective commitment in mediating employees' positive appraisal of management practices (GHRM) and employees' positive behavior [32]. As a result, organizations should use green HR strategies as a powerful method for motivating workers to care about the environment, allowing them to demonstrate sustainability. Coinciding with the mediation effect of affective commitment with the CSR and OP relation $[22,43,73]$ this study also found a positive significant effect. 


\subsection{Theoretical Contribution}

To the best of the researchers' understanding, this is the first empirical study of GHRM and CSR for better sustainable organizational performance in the Nepalese construction industry through the prism of stakeholder and AMO theories. The present study added to the body of knowledge on green human resource management practices and corporate social responsibility in the pursuit of improved organizational performance towards society, environment, and sustainability. The findings of this study make a remarkable contribution to fulfill the literature gap.

The study concluded that all hypothesized relationships proved significant with respect to the GHRM and CSR attributes in the construction sector. Prioritization of competence building among the employees can improve the sustainable organizational image. The construction sector is a major industry, including many employees belonging to the younger generation. This younger generation must have clear ideas and beliefs on global environmental changes and solutions needed for global protection of the environment in all fields of work. The possible use of this research is to focus on and reinforce the major human resource management system of the construction sector. This study included the valley, which is one of the centralized developed areas of a developing country. Moreover, the concerned authority should implement social responsibility, including green perspectives, with a better action plan and decentralize the system to obtain equity in the strategic management system. Thus, the top-level staff should upgrade their skills through training programs regarding green training, and employee involvement in every green activity of the organization and employees' responsibility to society. This will help employees to comprehend and to enhance their awareness of the sustainable approach regarding the importance of environmental and social management.

Findings from the study revealed the competitive partial mediation effect of affective commitment on the CSR, GHRM, and OP relation. The construction firms must consider various motivating training programs to achieve the organization's sustainable performance with the employees' full commitment towards the organization. Ultimately, employees' commitment ensures the long-term vision of an organization. Moreover, transformational leadership boosts the employee's perception of support from a superior level, consequently improving the quality of the organizational target goal. Hence, construction firms must also consider improving their leadership to have a quality and sustainable organization.

\subsection{Implication for Managers}

The findings of the current study will help policymakers of the construction companies in re-shaping the pro-environmental behavior of the stakeholders. GHRM practices will help to attract and retain such candidates who have an environmentally friendly mindset, attitude, and awareness. Furthermore, it will motivate stakeholders to put extra effort towards environmental activities initiated by firms. Similarly, corporate social responsibility helps the firms to increase and enhance their image in the eyes of stakeholders by participating in social activities, such as free education, medical facilities, and an environmentally protected climate, providing benefits to consumers and business partners. Focusing on these areas can support organizations in motivating their employee participation in decreasing environmental deterioration, enabling proper information for employees about pro-environmental activities, and adopting environmentally friendly behavior that will result in enhanced long-term performance.

Moreover, managers should invest in environmental training to improve environmental knowledge and awareness and boost employee understanding of green behavior. Furthermore, consideration of CSR actions during the routine operations helps to gain a competitive advantage and maintain a balance between advancement and environmental sustainability. 


\section{Conclusions}

This research has identified in the literature that sustainable organizational performance is the major agenda of companies nowadays. There are various organizational and employee variables that directly or indirectly influence the performance of the organization. However, past literature lacks in the important role of such factors in a firm's performance in the context of developing countries such as Nepal, where development is starting to pick up and construction organizations are in a gradual growth phase. Additionally, construction organizations of the developing states still need to research further on how to integrate these human resource practices, including the green concept.

Businesses focus on various areas of corporate social responsibility, such as stakeholders' interests, public social security, and environmental sustainability. Green human resource management will guarantee achieving stakeholders' needs and environmental commitments. Since it focuses on the preservation and protection of natural resources, as well as the minimization of waste, GHRM practices aid in the development of biodiversity. As a result, there is a close connection between CSR, GHRM, and sustainability. The organization needs to comply with both the green aspect and social responsibility to meet the sustainability of its operations and performance.

This study had a limitation of cross-sectional design, which cannot establish a causal relationship between variables, so future research may use a longitudinal design to help confirm these results in the long run. Moreover, it is suggested that a qualitative study on this sector with similar variables might contribute to extending the literature. An in-depth analysis of the study will be more fruitful, as will clarity of the core concern of the study with regard to future research. Further, though some prior researchers have conducted comparative studies, focus on the developing versus developed country might show improvement aspects required in the construction firms for maintaining sustainability. Furthermore, construction companies are just a corner of development, but future studies should consider other industries, such as manufacturing companies and transportationbased companies responsible for the development perspective and sustainable approach.

Author Contributions: Conceptualization, M.K, Y.C.; methodology, M.K., W.H.; formal analysis, M.K., Y.C.; investigation, M.K.; resources, M.K.; data curation, M.K., W.H., F.A.; writing-original draft preparation, M.K.; writing —review and editing, M.K, F.Z.; visualization, M.K., F.A.; supervision, F.Z.; funding acquisition, F.Z.; project administration, Y.C., validation, W.H., D.S. All authors have read and agreed to the published version of the manuscript.

Funding: This research received support from the National Social Science Fund (20FGLB047).

Institutional Review Board Statement: The study was conducted according to the guidelines of the Declaration of Helsinki, and following the academic ethics.

Informed Consent Statement: Informed content was obtained from all the subjects involved in this study.

Data Availability Statement: The detailed data of survey outcomes used to support the findings of this study are available from the corresponding author upon request.

Conflicts of Interest: The authors declare no conflict of interest. 


\section{Appendix A}

\begin{tabular}{|c|c|c|c|}
\hline Constructs & Cronbach's Alpha & Measurement Items & References \\
\hline $\begin{array}{l}\text { Green Transformational } \\
\text { Leadership (GTL) }\end{array}$ & 0.908 & $\begin{array}{l}\text { GTL1: Provides a clear environmental vision for the project members to follow } \\
\text { GTL2: Encourages the project members to achieve the environmental goals } \\
\text { GTL3: Considering environmental beliefs of the project members } \\
\text { GTL4: Stimulates the project members to think about green ideas } \\
\text { GTL5: Inspires the project members with the environmental plans }\end{array}$ & [74-76] \\
\hline $\begin{array}{c}\text { Corporate Social } \\
\text { Responsibility (CSR) }\end{array}$ & 0.858 & $\begin{array}{l}\text { CSR1: Provides training and construction to develop employees' skillsets } \\
\text { CSR2: Communicates complete and accurate information about the service to } \\
\text { customers } \\
\text { CSR3: Donates to charitable organizations } \\
\text { CSR 4: Applies high standard for disclosure, accounting, auditing, social, and } \\
\text { environmental editing }\end{array}$ & {$[77,78]$} \\
\hline $\begin{array}{l}\text { Affective Commitment } \\
\text { (AC) }\end{array}$ & 0.912 & $\begin{array}{l}\text { AC1: Employees believe in the value of environmental management for the trust } \\
\text { AC2: Employees think environmental management is a good strategy for the } \\
\text { trust } \\
\text { AC3: Employees think management is making a mistake by investing in } \\
\text { reducing the environmental impact of the trust }\end{array}$ & $\begin{array}{l}\text { [79] } \\
\text { [79] }\end{array}$ \\
\hline $\begin{array}{c}\text { Organizational } \\
\text { Performance (OP) }\end{array}$ & 0.893 & $\begin{array}{l}\text { OP1: Financial perspective } \\
\text { OP2: Customer perspective } \\
\text { OP3: Internal process perspective } \\
\text { OP4: Learning and growth perspective }\end{array}$ & {$[15,79]$} \\
\hline $\begin{array}{l}\text { Perceived Organizational } \\
\text { Support (POS) }\end{array}$ & 0.869 & $\begin{array}{l}\text { POS1: My success and innovation are recognized and celebrated } \\
\text { POS2: Have the information I need to do my job effectively } \\
\text { POS3: Have flexibility in my work schedule to meet both my business objectives } \\
\text { and my personal commitments } \\
\text { POS4: I am empowered to make necessary decisions when management is } \\
\text { absent }\end{array}$ & {$[59,74,80]$} \\
\hline $\begin{array}{l}\text { Green Human Resource } \\
\text { Management (GHRM) }\end{array}$ & 0.937 & $\begin{array}{l}\text { GHRM1: Employee appraisals emphasize environmental skills and } \\
\text { competences } \\
\text { GHRM2: Environmental training is a priority compared to other types of } \\
\text { training } \\
\text { GHRM3: Employees are allowed to make decisions concerning environmental } \\
\text { opportunities } \\
\text { GHRM4: Employees are provided the opportunity to suggest improvements on } \\
\text { environmental issues }\end{array}$ & {$[37,81,82]$} \\
\hline
\end{tabular}

\section{References}

1. Suganthi, L. Examining the relationship between corporate social responsibility, performance, employees' pro-environmental behavior at work with green practices as mediator. J. Clean. Prod. 2019, 232, 739-750. [CrossRef]

2. Ahmed, M.; Zehou, S.; Raza, S.A.; Qureshi, M.A.; Yousufi, S.Q. Impact of CSR and environmental triggers on employee green behavior: The mediating effect of employee well-being. Corp. Soc. Responsib. Environ. Manag. 2020, 27, 2225-2239. [CrossRef]

3. Jackson, S.E.; Renwick, D.W.S.; Jabbour, C.J.C.; Muller-Camen, M. State-of-the-art and future directions for green human resource management. Ger. J. Res. Hum. Resour. Manag. 2011, 25, 99-116. [CrossRef]

4. García-Morales, V.J.; Jiménez-Barrionuevo, M.M.; Gutiérrez-Gutiérrez, L. Transformational leadership influence on organizational performance through organizational learning and innovation. J. Bus. Res. 2012, 65, 1040-1050. [CrossRef]

5. Abdallah, A.B.; Al-Ghwayeen, W.S. Green supply chain management and business performance: The mediating roles of environmental and operational performances. Bus. Process Manag. J. 2019, 26, 489-512. [CrossRef]

6. Achieng Owino, W. Influence of Selected Green Human Resource Management Practices on Environmental Sustainability at Menengai Oil Refinery Limited Nakuru, Kenya. J. Hum. Resour. Manag. 2016, 4, 19-27. [CrossRef]

7. Pinzone, M.; Guerci, M.; Lettieri, E.; Redman, T. Progressing in the change journey towards sustainability in healthcare: The role of “Green” HRM. J. Clean. Prod. 2016, 122, 201-211. [CrossRef]

8. Loosemore, M.; Lim, B.T.H. Linking corporate social responsibility and organizational performance in the construction industry. Constr. Manag. Econ. 2017, 35, 90-105. [CrossRef]

9. Kim, D.; Cho, W.; Allen, B. Sustainability of social economy organizations (SEOs): An analysis of the conditions for surviving and thriving. Soc. Sci. J. 2020, 1-17. [CrossRef]

10. Benn, S.; Teo, S.T.T.; Martin, A. Employee participation and engagement in working for the environment. Pers. Rev. 2015, 44, 492-510. [CrossRef]

11. Aust, I.; Matthews, B.; Muller-Camen, M. Common Good HRM: A paradigm shift in Sustainable HRM? Hum. Resour. Manag. Rev. 2020, 30, 100705. [CrossRef] 
12. Langat, B.; Kwasira, J. Influences of Green Human Resource Management Practices on Environmental Sustainability At Kenyatta University, Kenya. Int. J. Econ. Commer. Manag. 2016, 4, 986-1003.

13. Bombiak, E.; Marciniuk-Kluska, A. Green human resource management as a tool for the sustainable development of enterprises: Polish young company experience. Sustainability 2018, 10, 1739. [CrossRef]

14. Freitas, W.R.d.S.; Caldeira-Oliveira, J.H.; Teixeira, A.A.; Stefanelli, N.O.; Teixeira, T.B. Green human resource management and corporate social responsibility: Evidence from Brazilian firms. Benchmarking 2020, 27, 1551-1569. [CrossRef]

15. Mehralian, G.; Nazari, J.A.; Zarei, L.; Rasekh, H.R. The effects of corporate social responsibility on organizational performance in the Iranian pharmaceutical industry: The mediating role of TQM. J. Clean. Prod. 2016, 135, 689-698. [CrossRef]

16. He, J.; Morrison, A.M.; Zhang, H. Being sustainable: The three-way interactive effects of CSR, green human resource management, and responsible leadership on employee green behavior and task performance. Corp. Soc. Responsib. Environ. Manag. 2021, 28, 1043-1045. [CrossRef]

17. Albuquerque, R.; Koskinen, Y.; Zhang, C. Corporate social responsibility and firm risk: Theory and empirical evidence. Manag. Sci. 2019, 65, 4451-4469. [CrossRef]

18. Ofori, D.F.; Nyuur, R.B.; S-Darko, M.D. Corporate social responsibility and financial performance: Fact or fiction? A look at Ghanaian banks. Acta Commer. 2014, 14, 1-11. [CrossRef]

19. Shen, J.; Zhang, H. Socially responsible human resource management and employee support for external CSR: Roles of organizational CSR climate and perceived CSR directed toward employees. J. Bus. Ethics 2019, 156, 875-888. [CrossRef]

20. Shen, J.; Jiuhua Zhu, C. Effects of socially responsible human resource management on employee organizational commitment. Int. J. Hum. Resour. Manag. 2011, 22, 3020-3035. [CrossRef]

21. Story, J.S.P.; Castanheira, F. Corporate social responsibility and employee performance: Mediation role of job satisfaction and affective commitment. Corp. Soc. Responsib. Environ. Manag. 2019, 26, 1361-1370. [CrossRef]

22. McLaughlin, C. Corporate Social Responsibility and Human Resource Management. Hum. Resour. Manag. 2019, 273-292. [CrossRef]

23. Mishra, P. Green human resource management: A framework for sustainable organizational development in an emerging economy. Int. J. Organ. Anal. 2017, 25, 762-788. [CrossRef]

24. Renwick, D.; Redman, T.; Maguire, S. Green HRM: Teaching and learning guide. Int. J. Manag. Rev. 2013. [CrossRef]

25. Yoon, B.; Chung, Y. The effects of corporate social responsibility on firm performance: A stakeholder approach. J. Hosp. Tour. Manag. 2018, 37, 89-96. [CrossRef]

26. Freeman, E. Strategic Management-A Stakeholder Approach; Pitman: Boston, MA, USA, 1984.

27. Malik, S.Y.; Mughal, Y.H.; Azam, T.; Cao, Y.; Wan, Z.; Zhu, H.; Thurasamy, R. Corporate social responsibility, green human resources management, and sustainable performance: Is organizational citizenship behavior towards environment the missing link? Sustainability 2021, 13, 1044. [CrossRef]

28. Zhao, Z.-Y.; Zhao, X.-J.; Davidson, K.; Zuo, J. A corporate social responsibility indicator system for construction enterprises. J. Clean. Prod. 2012, 29, 277-289. [CrossRef]

29. Jones, P.; Comfort, D.; Hillier, D. Corporate social responsibility and the UK construction industry. J. Corp. Real Estate 2006, 8, 134-150. [CrossRef]

30. Amrutha, V.N.; Geetha, S.N. A systematic review on green human resource management: Implications for social sustainability. J. Clean. Prod. 2020, 247, 119131. [CrossRef]

31. Jabbour, C.J.C. How green are HRM practices, organizational culture, learning and teamwork? A Brazilian study. Ind. Commer. Train. 2011, 43, 98-105. [CrossRef]

32. Zaid, A.A.; Jaaron, A.A.M.; Talib Bon, A. The impact of green human resource management and green supply chain management practices on sustainable performance: An empirical study. J. Clean. Prod. 2018. [CrossRef]

33. Gill, A.; Ahmad, B.; Kazmi, S. The effect of green human resource management on environmental performance: The mediating role of employee eco-friendly behavior. Manag. Sci. Lett. 2021, 11, 1725-1736. [CrossRef]

34. Haddock-Millar, J.; Sanyal, C.; Müller-Camen, M. Green human resource management: A comparative qualitative case study of a United States multinational corporation. Int. J. Hum. Resour. Manag. 2016, 27, 192-211. [CrossRef]

35. Arulrajah, A.A.; Opatha, H.H.D.N.P. Analytical and Theoretical Perspectives on Green Human Resource Management: A Simplified Underpinning. Int. Bus. Res. 2016, 9, 153. [CrossRef]

36. Eisenberger, R.; Huntington, R.; Hutchison, S.; Sowa, D. Eisenberger 1986 JAppPsychol POS original article. J. Appl. Psychol. 1986, 71, 500-507. [CrossRef]

37. Nazir, S.; Qun, W.; Hui, L.; Shafi, A. Influence of social exchange relationships on affective commitment and innovative behavior: Role of perceived organizational support. Sustainability 2018, 10, 4418. [CrossRef]

38. Liu, Y. Perceived organizational support and expatriate organizational citizenship behavior: The mediating role of affective commitment towards the parent company. Pers. Rev. 2009, 38, 307-319. [CrossRef]

39. Rubel, M.R.B.; Kee, D.M.H.; Rimi, N.N. The influence of green HRM practices on green service behaviors: The mediating effect of green knowledge sharing. Empl. Relations Int. J. 2021, 43, 996-1015. [CrossRef]

40. Stinglhamber, F.; Marique, G.; Caesens, G.; Desmette, D.; Hansez, I.; Hanin, D.; Bertrand, F. Employees' organizational identification and affective organizational commitment? An integrative approach. PLoS ONE 2015, 10, e0123955. [CrossRef] 
41. Ribeiro, N.; Yucel, I.; Gomes, D. How Transformational Leadership predicts Employees' Affective Commitment and Performance. Int. J. Product. Perform. Manag. 2018, 67, 1901-1917. [CrossRef]

42. Sharma, J.; Dhar, R.L. Factors influencing job performance of nursing staff: Mediating role of affective commitment. Pers. Rev. 2016, 45, 161-182. [CrossRef]

43. Kim, Y.J.; Kim, W.G.; Choi, H.M.; Phetvaroon, K. The effect of green human resource management on hotel employees' eco-friendly behavior and environmental performance. Int. J. Hosp. Manag. 2019, 76, 83-93. [CrossRef]

44. Koohang, A.; Paliszkiewicz, J.; Goluchowski, J. The impact of leadership on trust, knowledge management, and organizational performance: A research model. Ind. Manag. Data Syst. 2017, 117, 521-537. [CrossRef]

45. Dechant, K.; Altman, B. Environmental leadership: From compliance to competitive advantage. Acad. Manag. Perspect. 1994, 8, 7-20. [CrossRef]

46. Zhang, Y.; Zheng, J.; Darko, A. How does transformational leadership promote innovation in construction? The mediating role of innovation climate and the multilevel moderation role of project requirements. Sustainability 2018, 10, 1506. [CrossRef]

47. Khan, H.R.; Ali, M.; Olya, H.G.T.; Zulqarnain, M.; Khan, Z.R. Transformational leadership, corporate social responsibility, organizational innovation, and organizational performance: Symmetrical and asymmetrical analytical approaches. Corp. Soc. Responsib. Environ. Manag. 2018, 25, 1270-1283. [CrossRef]

48. Berberoglu, A. Impact of organizational climate on organizational commitment and perceived organizational performance: Empirical evidence from public hospitals. BMC Health Serv. Res. 2018, 18, 399. [CrossRef]

49. Hair, J.F.; Black, B.; Babin, B.; Anderson, R.E.; Tatham, R.L. Multivariate Data Analysis: A Global Perspective; Pearson Education Inc.: Cranbury, NJ, USA, 2010.

50. Fornell, C.; Larcker, D.F. Evaluating structural equation models with unobservable variables and measurement error. J. Mark. Res. 1981, 18, 39-50. [CrossRef]

51. Chinn, W.W. The Partial Least Squares Approach to Structural Equation Modelling. Mod. Methods Bus. Res. 1998, $295,295-336$.

52. Aibinu, A.A.; Al-Lawati, A.M. Using PLS-SEM technique to model construction organizations' willingness to participate in e-bidding. Autom. Constr. 2010, 19, 714-724. [CrossRef]

53. Farooq, O.; Payaud, M.; Merunka, D.; Valette-Florence, P. The Impact of Corporate Social Responsibility on Organizational Commitment: Exploring Multiple Mediation Mechanisms. J. Bus. Ethics 2014, 125, 563-580. [CrossRef]

54. Rettab, B.; Brik, A.B.; Mellahi, K. A study of management perceptions of the impact of corporate social responsibility on organisational performance in emerging economies: The case of Dubai. J. Bus. Ethics 2009, 89, 371-390. [CrossRef]

55. Rawashdeh, A.M. The impact of green human resource management on organizational environmental performance in Jordanian health service organizations. Manag. Sci. Lett. 2018, 8, 1049-1058. [CrossRef]

56. Ali, I.; Rehman, K.U.; Ali, S.I.; Yousaf, J.; Zia, M. Corporate social responsibility influences, employee commitment and organizational performance. Afr. J. Bus. Manag. 2010, 4, 2796-2801.

57. Christensen, L.J.; Mackey, A.; Whetten, D. Taking responsibility for corporate social responsibility: The role of leaders in creating, implementing, sustaining, or avoiding socially responsible firm behaviors. Acad. Manag. Perspect. 2014, 28, 164-178. [CrossRef]

58. Carmeli, A.; Gilat, G.; Waldman, D.A. The role of perceived organizational performance in organizational identification, adjustment and job performance. J. Manag. Stud. 2007, 44, 972-992. [CrossRef]

59. Green, A.E.; Miller, E.A.; Aarons, G.A. Transformational leadership moderates the relationship between emotional exhaustion and turnover intention among community mental health providers. Community Ment. Health J. 2013, 49, 373-379. [CrossRef]

60. Ditlev-Simonsen, C.D. The Relationship Between Norwegian and Swedish Employees' Perception of Corporate Social Responsibility and Affective Commitment. Bus. Soc. 2015, 54, 229-253. [CrossRef]

61. Glavas, A.; Kelley, K. The Effects of Perceived Corporate Social Responsibility on Employee Attitudes. Bus. Ethics Q. 2014, 24, 165-202. [CrossRef]

62. Glavas, A. Corporate social responsibility and employee engagement: Enabling employees to employ more of their whole selves at work. Front. Psychol. 2016, 7, 1-10. [CrossRef]

63. Hair, J.F.; Risher, J.J.; Sarstedt, M.; Ringle, C.M. When to use and how to report the results of PLS-SEM. Eur. Bus. Rev. 2019, 31, 2-24. [CrossRef]

64. Sukamani, D.; Wang, J. SEM Model for Investigating Factor of an Accident Affecting Safety Performance in Construction Sites in Nepal. Eng. Lett. 2020, 28, 783-795.

65. Ahmeda, U.; Mozammelb, S.; Zamanc, F. Green HRM and Green Innovation: Can Green Transformational Leadership Moderate: Case of Pharmaceutical Firms in Australia. Syst. Rev. Pharm. 2020, 11, 616-617.

66. O'Donohue, W.; Torugsa, N.A. The moderating effect of 'Green' HRM on the association between proactive environmental management and financial performance in small firms. Int. J. Hum. Resour. Manag. 2016, 27, 239-261. [CrossRef]

67. Sharma, R.; Gupta, N. Green HRM: An Innovative Approach to Environmental Sustainability. In Proceedings of the Twelfth AIMS International Conference on Management, Kozhikode, India, 2-5 January 2010; Volume 12, pp. 825-830.

68. Mousa, S.K.; Othman, M. The impact of green human resource management practices on sustainable performance in healthcare organisations: A conceptual framework. J. Clean. Prod. 2020, 243, 118595. [CrossRef]

69. Luzzini, D.; Longoni, A.; Guerci, M. Green HRM and SCM practices and their effects on environmental and economic performance. Acad. Manag. Proc. 2014, 1, 13491. [CrossRef] 
70. Yoon, S.K.; Kim, J.H.; Park, J.E.; Kim, C.J.; Song, J.H. Creativity and knowledge creation: The moderated mediating effect of perceived organizational support on psychological ownership. Eur. J. Train. Dev. 2020, 44, 743-760. [CrossRef]

71. Zagenczyk, T.J.; Gibney, R.; Few, W.T.; Scott, K.L. Psychological contracts and organizational identification: The mediating effect of perceived organizational support. J. Labor Res. 2011, 32, 254-281. [CrossRef]

72. Ansari, N.Y.; Farrukh, M.; Raza, A. Green human resource management and employees pro-environmental behaviours: Examining the underlying mechanism. Corp. Soc. Responsib. Environ. Manag. 2021, 28, 229-238. [CrossRef]

73. Podsakoff, P.M.; MacKenzie, S.B.; Bommer, W.H. Transformational leader behaviors and substitutes for leadership as determinants of employee satisfaction, commitment, trust, and organizational citize. J. Manag. 1996, 22, 259-298. [CrossRef]

74. Chen, Y.S.; Chang, C.H. The Determinants of Green Product Development Performance: Green Dynamic Capabilities, Green Transformational Leadership, and Green Creativity. J. Bus. Ethics 2013, 116, 107-119. [CrossRef]

75. Singh, S.K.; Giudice, M.D.; Chierici, R.; Graziano, D. Green innovation and environmental performance: The role of green transformational leadership and green human resource management. Technol. Forecast. Soc. Chang. 2020, 150, 119762. [CrossRef]

76. Yuen, K.F.; Thai, V.V.; Wong, Y.D.; Wang, X. Interaction impacts of corporate social responsibility and service quality on shipping firms' performance. Transp. Res. Part A Policy Pract. 2018, 113, 397-409. [CrossRef]

77. Carroll, A.B.; Shabana, K.M. The business case for corporate social responsibility: A review of concepts, research and practice. Int. J. Manag. Rev. 2010, 12, 85-105. [CrossRef]

78. Neves, P.C.; Paixão, R.; Alarcão, M.; Gomes, A.D. Organizational citizenship behavior in schools: Validation of a questionnaire. Span. J. Psychol. 2014, 17, 1-8. [CrossRef]

79. Paillé, P.; Chen, Y.; Boiral, O.; Jin, J. The Impact of Human Resource Management on Environmental Performance: An EmployeeLevel Study. J. Bus. Ethics 2014, 121, 451-466. [CrossRef]

80. Lamm, E.; Tosti-Kharas, J.; King, C.E. Empowering Employee Sustainability: Perceived Organizational Support Toward the Environment. J. Bus. Ethics 2015, 128, 207-220. [CrossRef]

81. Tang, G.; Chen, Y.; Jiang, Y.; Paillé, P.; Jia, J. Green human resource management practices: Scale development and validity. Asia Pac. J. Hum. Resour. 2018, 56, 31-55. [CrossRef]

82. Gupta, H. Assessing organizations performance on the basis of GHRM practices using BWM and Fuzzy TOPSIS. J. Environ. Manag. 2018, 226, 201-216. [CrossRef] 